\title{
SOME THOUGHTS ON THE REPAYMENT METHODS OF HUNGARIAN HOUSEHOLD FOREX LOANS ${ }^{1}$
}

\author{
Barbara Sepsi \& Veronika Fenyves
}

University of Debrecen

\begin{abstract}
Nowadays the volatility of exchange rates and the macroeconomic changes strongly affect the monthly instalments of the debtors. The growth of delayed forex loans - mostly denominated in Swiss Franc and Euro - can include a high risk, which as a part of a vicious circle can ruin Hungary's economic situation and even the country's external judgement. Steps were taken to handle the problem of the forex loans but their result is questionable. In this paper different repayment methods are compared in different economic scenarios. More precisely, the third edition of exchange-rate barrier and income based repayment are analysed in an optimistic realistic and pessimistic scenario. This article is aiming to quantify and interpret the difference between each repayment methods regarding different scenarios. Based on the results suggestions are made how to eliminate efficiently currency exposure from the continuously deteriorating portfolio.
\end{abstract}

Keywords: forex loans, delayed loans, repayment methods, exchange-rate barrier, income based repayment, Euro, Swiss Franc

\section{Introduction}

A wide range of offers are available in borrowing from a credit institution nowadays. Foreign currency based loans were also available in 1990s, but their growth became significant only after 2005. These loans were mostly denominated in Swiss Franc, Euro and Japanese Yen (Balás-Nagy 2010). After $2008,66 \%$ of the loans were denominated in foreign currency, which meant a high level of foreign exposure (MNB).

High budget deficit and national debt (out of which a significant part is also denominated in foreign currency) characterized the Hungarian economy. It is not unusual that the government's response was to levy taxes, but it happened parallel to increasing unemployment rates (Burgerné 2011). Consequently, people did not have the capacity to save money, which led to the lack of internal savings, making banks less well-funded. The demand of capital made the banks turn to foreign funding. Lower liquidity of the population is also appeared in growing application for loans (7Sigma 2010) and spending freely usable mortgage credits to consumption, taking a maturity risk besides the already existing interest and exchange risks (Holmár 2012). This way foreign exposure continuously increased, which reflected in the CDS-spreads and the ratings of Hungary (Varga 2008).
Thanks to the abovementioned negative facts the foreign sources became more and more expensive; moreover, there was not still any internal saving tendency. The additional costs were passed on to the debtors in a way interest rates were increased (which is strictly regulated since then thanks to Act CXLVIII of 2011). It was getting harder and harder to pay the growing costs of the loans. Furthermore, the debtors were also the victim of the depreciation of Forint this time, which altogether resulted in the deterioration of the portfolio. The ratio of non-performing loans is considered to be high in Hungary. The bad quality of the loan portfolio can charge extra costs to the government - originating unexpected expenses - leading higher budget deficit and national debt than expected (Figure 1).

\section{What is happening with forex loans?}

In the present economic situation a forex loan could have several outcomes thanks to the aids carried out by the banks and the government. If there was no delay or less than 90 days, debtors could choose from the first and second edition of "exchange-rate barrier" or the early repayment (Act LXXV of 2011). There were also restructuring opportunities offered by

\footnotetext{
${ }_{1}$ This research was supported by the European Union and the State of Hungary, co-financed by the European Social Fund in the framework of TÁMOP 4.2.4. A/2-11-1-2012-0001 'National Excellence Program - Elaborating and operating an inland student and researcher personal support system, was realised with personal support
} 
banks. But if we consider a non-performing loans, we should divide them into two groups: loans deferred more than 90 but less than 180 days and loans overdue more than 180 days. It is necessary to distinguish the mentioned loans, because the third exchange rate barrier scheme was extended to be available for loans with 90-180 days delay (Act CLXXIII of 2013). There was no official, collective aid in case of loans with $180+$ days delay. National Asset Management Agency (NAMA) was established to handle totally insolvent debtors' situation. NAMA is the government agency responsible for ensuring the debtors proper life circumstances after enforcing the mortgage (Government Decree 128/2012 describes its operation). NAMA's working efficiency is limited so as their financial resources (to handle the problem of mortgages) although the government decided on their processes and resources long before. Hungary is not the only European country facing the volatile nature of forex mortgage credit.

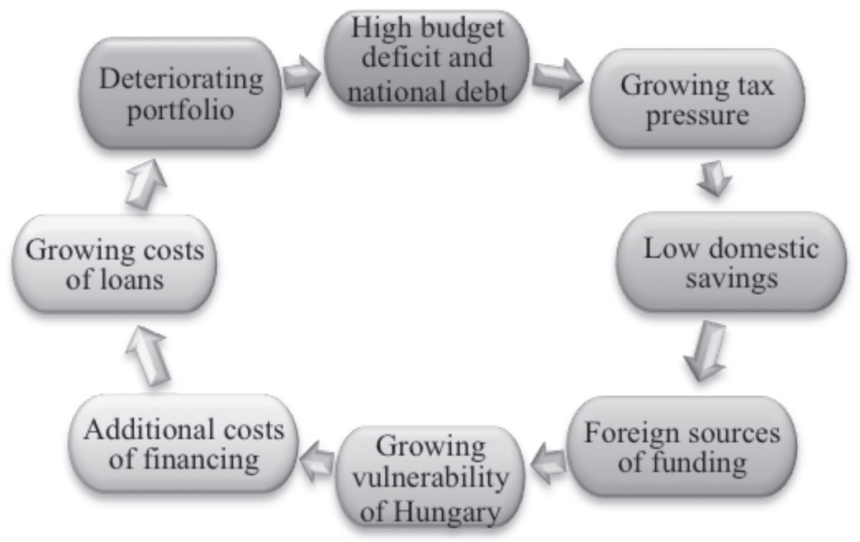

Figure 1. Vicious circle regarding forex loans' background Source: Own figure

\section{Similar situations abroad}

Hungary is not the only European country facing the negative effects of the financial turmoil. High non-performing loan ratio characterises Romanian and Polish loan portfolio too. Hudecz (2012) compares Poland and Romania with Hungary due to the similar stock of forex credits and the social and economic structure of each country.

\section{Poland}

The polish portfolio is made up of approximately $50 \%$ of PLN loans, $40 \%$ of CHF based loans and $10 \%$ other forex loans. (PNB) It is not the first time Poland has to react to exchange rate and interest rate volatility. In the beginning of the millennium they did take acts to call the population's attention the risk they were taking by choosing forex loans instead of PLN loans (Hudecz 2012) Still, mortgage backed loans were not popular there because the ownership of real estates is $30 \%$ lower than in Hungary. Another interesting fact is the much looser mortgage regulation, which makes the banks almost impossible to enforce the mortgage in case of a defaulted loan. According to the polish legal practise it is not compulsory to record the mortgage to the land register only if the creditor insists on it. If this step is left out of the procedure, the debtor is free to sell the real estate before the mortgage is enforced. Additionally, the debtors cannot be evicted until there is another real estate they can move into. The creditors or the local government is responsible for providing a new real estate in the first place not the debtor. There is also advantage of not having a high amount of mortgage credit; they are not likely to use the money for consumption in contrary to Hungary, where this is the tendency (Dübel 2012).

Informative steps are playing a key role in the polish banking practice. Banks offer obligatorily Zloty (PLN) loans first and if it is not suitable for the debtors, then are they empowered to offer forex loans. In this case debtors are compulsorily informed of the effects regarding the monthly obligation generated by a $20 \%$ interest rate and exchange rate fluctuation. The initial instalment is maximised as $42 \%$ of the debtor's net income. The opportunity is given to repay the forex loan in the given foreign currency (Hudecz 2012). The defaulted loans are converted into Zloty and handled as a PLN loan afterwards. In order to help the insolvent debtors the government introduced the "personal bankruptcy" from 2009. It is considered to be a successful step because the social tensions eased since then.

\section{Romania}

During the analysis of the Romanian situation we should consider the fact that the transition to a market economy started 10 years later as in Hungary. The stock of household lending began to grow only after 2004, this time is characterised by the growing demand of real estates and consumer durables. At the same time more and more people chose to work abroad. $10 \%$ of the working age population are working outside of Romania, so notable amount of the income is remitted back to the country in Euro (mostly). Due to the abovementioned facts $80 \%$ of the portfolio is made up of Euro based loans. Additionally, 30\% appreciation of the national currency (Leu - RON) against the euro between 2004 and 2007 encouraged the debtors to choose euro based loans. After 2007 Swiss Franc and Japanese Yen based loans also appeared besides the Euro based ones (Dübel 2012). The Romanian National Bank tried to make steps to make the RON loans more attractive, but there was no harmony between the orders so it was not successful. The ratio of defaulted forex loans equals to the Hungarian data: 23,4\% (RNB) The Romanian government denotes the introduction of Euro urgent due to solve the defaulted forex loans' problem among others (Nyeste-Árokszállási 2012).

The same factors of the three countries: all countries are post-socialist country, whose inhabitants (mostly) were not socialized in a market economy so that their financial literature can be limited; due to the recession the countries' loans offered in domestic currency were not attractive, so the debtors turned to the cheaper foreign currency based loans; 
and the appreciations and depreciations were possible thanks to the floating exchange rate system used by all the three countries. Regarding the reactions of the countries: both Poland and Romania made an effort to fix the instalments to the income and Poland managed to introduce personal bankruptcy as a successful procedure.

\section{Materials and methods}

Two loan conditions provided the basis for my calculations: a Euro and a Swiss Franc based loan. To ensure comparability the conditions of these two loans were the same except for the currency and the interest rate. During my calculations only interest rates are implied in the results because other cost can be different in the mentioned currencies. The characteristics of the analysed loans are demonstrated in Table 1 .

Table 1. Characteristics of the analysed loans

\begin{tabular}{|l|c|c|}
\hline & CHF & EUR \\
\hline Disbursed loan (HUF) & 5 million & 5 million \\
\hline Duration (years) & 20 & 20 \\
\hline Interest rate (\%) & 2,49 & 3,99 \\
\hline Time of contract & 1st July 2005 & 1st July 2005 \\
\hline First repayment & 1st August 2005 & 1st August 2005 \\
\hline Collateral & mortgage & mortgage \\
\hline $\begin{array}{l}\text { Calculating method of the } \\
\text { instalment }\end{array}$ & annuity & annuity \\
\hline
\end{tabular}

Source: Own data

Annuity is used usually by banks to calculate the monthly debt payment. This method assures that there will be fixed amount of burden should be paid monthly. The fix instalment denotes the sum of the interest and capital costs. Each month both components are represented in different ratio, but their sum is always given (Sándorné, 2003). In case of foreign mortgage credits annuity is carried out by the loan denominated in the given currency. Each month different amount of interest and capital costs are converted to Hungarian Forint using the current exchange rates.

Several debtors were not capable of paying the monthly burden or if yes with a delay. The ratio of non-performing loans - loan are overdue more than 90 days (Bloem - Freeman, 2005) - represents a high value $(23,4 \%)$ in Hungary and it is continuously growing. (MNB)

\section{Exchange-rate barrier}

According to the Act CLXXIII of 2013 there is an opportunity for a part of debtors to join the government-backed exchange rate cap system. It is a third edition of the program, the first and the second edition was aiming to help debtors with a maximum 90 days overdue loans. This Act widened the range of potential applicants: it is available for part of debtors having non-performing loans up to 180 days delay.

This method includes a temporary period of repayment at a fixed exchange rate applying two different exchange rates for the same time. One of them is the current rate and the other is a fixed rate - in the case of Swiss Franc $180 \mathrm{HUF} / \mathrm{CHF}$ and of Euro $250 \mathrm{HUF} / \mathrm{CHF}$. If the current exchange rate exceeds the fix one, the amount above is multiplied by the given capital cost and get automatically transferred to a separate account and handled as a HUF loan. Capital part of the HUF loan will be paid by the debtor after the grace period while interest part is paid $50-50 \%$ by the financial institution and the central budget (the debtors is released). If the HUF exchange rate exceeds $270 \mathrm{HUF} / \mathrm{CHF}$ or $340 \mathrm{HUF} / \mathrm{EUR}$, the exceeding part is paid totally by the central government. Except for the HUF interest rate (BUBOR for three months) on the debt collected on the separate account, imposing any fees or commissions by the institution is prohibited by the law (I2).

In the current analysis I assumed that the debtors utilize the maximum allowed time of a temporary period of fixed exchange rate, which is 60 months. After the mentioned temporary period the debtors are obliged to pay according to the original conditions besides the repayment of the HUF loan accumulated in the separate account with the interests $(7 \%$ in the following calculations).

\section{Income based repayment}

Income based repayment raised as an option for the solution of delayed forex loans. This paper intends to test that suggestion. Initially this method was used to pay off student loans. The ratio of non-performing loans regarding student loans are surprisingly low. This method may be applicable in case of mortgage credits also considering the collateral remains the real-estate the debtors are living in (Berlinger \& Walter 2013).

In the beginning of the examined period the foreign currency based loan is converted to HUF loan using the current exchange rate. This way we get the new principal outstanding by multiplication of the current exchange rate and the outstanding principle in December 2013. With the same method we can also calculate the interest outstanding.

To have a more concrete data for the analysis three groups of income category were distinguished (Table 2). Net incomes are assigned to each category and $40 \%$ of the income denotes the monthly fix repayment. I consider this ratio burdening, still payable for the people having only 120000 HUF/month. I also tried lower ratios in the models, which unfortunately resulted negative values so this is the lowest ratio possible. Therefore, in case of Category I my model excluded the interests outstanding because of the radically low income level. Income contingent repayment is advantages basically because it is proportional to the available in-

Table 2. Monthly net incomes of each category

\begin{tabular}{|l|c|}
\hline Category & Net income (HUF/month) \\
\hline Category I & $120000-199999$ \\
\hline Category II & $200000-280000$ \\
\hline Category III & $280000+$ \\
\hline
\end{tabular}

Source: Own data 
come, so debtors having higher income are able to get rid of the burden of the loan sooner. The same is true for debtors with lower income; they are able to calculate the fix instalments, which are lower comparing to the richer categories but lasts for a longer period. The lowest income is 120000 HUF monthly, this amount is the lowest possible assuming creditability. Categories are defined with 80000 HUF differences. Above $280000 \mathrm{HUF} / \mathrm{month}$ delayed repayment is not likely, unless speculative intention - waiting for a better chance with a greater discount.

The previously used technique of annuity is modified: the instalment is the ratio of the income. If we multiply the principal outstanding by the interest rate (per month) we will get the monthly interest. Capital repayment can be calculated by subtracting the monthly interest from the instalment.

According to the Act CXLVIII of 2011 the interest rate is either determine for 3, 5 or 10 years of time or fix it to a reference rate. In practice, there is also a premium for the lending institution. In the following scenarios only the interest is taken into consideration, because premiums related to every bank and/or customer can be completely different. My analysis presumes the interest rate constant during the duration.

\section{Scenarios}

It is a very complex task to forecast the exchange rates and interest rates for the future, besides the failure rate could be quite high. Therefore, three artificial scenarios were created: optimistic, realistic and pessimistic scenario. This way was chosen to measure the limits of the debtors' potential costs, losses or even profits. Different scenarios assume different exchange and interest rates regarding Swiss Franc and Euro based loans. The conditions of the income based repayment were designed in a way of applying a constantly decreasing interest rate relating to a higher income category (based on the fact that a debtor with higher income has a lower nonperforming risk).

\section{Optimistic scenario}

An economic environment, where the interest rates are low (so are the risks). More precisely the exchange rates are the following: $230 \mathrm{HUF} / \mathrm{CHF}$ and $290 \mathrm{HUF} / \mathrm{EUR}$. Three diminishing interest rates are assigned to the income categories Category I is described by $5 \%$, Category II by $4,5 \%$ and $4 \%$ is used in case of Category III. Both the interest and the exchange rates are not likely to reach the

\section{Realistic scenario}

I evaluate the realistic scenario similar to the numbers characterized the end of 2013 or the beginning of 2014. $230 \mathrm{HUF} /$ CHF and 290 HUF/EUR were the average exchange rates. In this case the applicable interest rates are Category I $-6 \%$, Category II $-5,5 \%$, Category III $-5 \%$.

\section{Pessimistic scenario}

The exchange rates of pessimistic scenario are worded in the conditions of the Exchange rate barrier: $270 \mathrm{HUF} / \mathrm{CHF}$ and $340 \mathrm{HUF} / \mathrm{EUR}$. Compared to the high exchange rates, high interest rates are presumable 7\% related to Category I, 6,5\% to Category II and 6\% to Category III.

\section{Results and discussion}

This paper demonstrates and interprets the result of comparing the original costs of forex loans with various repayment methods' costs. The goal is to find out with method would be beneficial for the debtors and whether there is a better solution than the exchange rate barrier. The following three tables summarise my calculations in case of different scenarios. During my calculations with income based repayment I applied the conversion at the beginning of 2014, therefore the principals are equal regardless of the scenario. However, I made an exception with the lowest income category (for social reasons), I assumed that the bank is not claiming the future interest, so it was subtracted from the principal.

\section{Optimistic scenario}

Optimistic scenario was tested with relatively low exchange and interest rates (Table 3). The interests of the CHF based loans are mostly under 2 million Forint, except for calculating with income category I. The significant growth here is resulted by the longer duration with more interest period. If we compare the proportion of the interest we can discover that the lower portion is represented in case of income category III. This consequently follows from the shorter duration. In terms of principal payment the original loan has the least cost, this is the only amount under 7 million Forint. In this scenario the income based repayment as for the CHF based loans are not beneficial regarding the total repayments.

Examining the results carried out with the EUR based loans, it is not surprising to note that the lowest interest cost belongs to the highest income category based repayment method - thanks to the short period of time and a high monthly instalment. An interesting result that the total cost of the lowest income category is lower than in case of exchange rate barrier, nevertheless, considering the foregone interest it would not be lower any longer. The lowest interest rate can be linked to Category III. and surprisingly the highest interest rate belongs to the exchange rate barrier. Analysing the principal costs, we can create three zones: the original loan has the least coast (5,7 million HUF), the exchange rate barrier and the category I. exceeds 6 million HUF and the higher income categories has the costs above 7 million HUF. The statement made in case of CHF loans above is also true if we consider the result of repayment methods of EUR based loans; income based repayment are not beneficial in the optimistic scenario. 
Table 3. Repaid amounts of CHF and EUR based loans in case of optimistic scenario

\begin{tabular}{|c|c|c|c|c|c|}
\hline Condition & Interest (HUF) & $\begin{array}{c}\text { Ratio of interest } \\
(\%)\end{array}$ & Principal (HUF) & $\begin{array}{l}\text { Ratio of princi- } \\
\text { pal (\%) }\end{array}$ & Total repayment (HUF) \\
\hline Original loan (CHF) & 1751561 & $20,29 \%$ & 6880961 & $79,71 \%$ & 8632521 \\
\hline Exchange rate barrier* & 1993658 & $22,34 \%$ & 7151674 & $80,14 \%$ & 8924249 \\
\hline Category I** & 2664600 & $27,00 \%$ & 7204040 & $73,00 \%$ & 9868640 \\
\hline Category II & 1985959 & $20,04 \%$ & 7921826 & $79,96 \%$ & 9907785 \\
\hline Category III & 1572296 & $16,56 \%$ & 7921826 & $83,44 \%$ & 9494122 \\
\hline Original loan (EUR) & 2561138 & $30,69 \%$ & 5785092 & $69,31 \%$ & 8346230 \\
\hline Exchange rate barrier* & 2711871 & $30,90 \%$ & 6063238 & $69,10 \%$ & 8775108 \\
\hline Category I** & 2632854 & $30,24 \%$ & 6073843 & $69,76 \%$ & 8706696 \\
\hline Category II & 2350860 & $24,70 \%$ & 7167298 & $75,30 \%$ & 9518158 \\
\hline Category III & 1996938 & $21,79 \%$ & 7167298 & $78,21 \%$ & 9164237 \\
\hline
\end{tabular}

*Capitalised interest in case of CHF based loan: $389253 \mathrm{Ft}$, and EUR based loan: $281953 \mathrm{Ft}$

**Foregone interest in case of CHF based loan: $764533 \mathrm{Ft}$, and EUR based loan $1069712 \mathrm{Ft}$

Source: Own calculations

\section{Realistic scenario}

Interest rates and exchange rates of realistic scenario reflect a situation where the circumstances would stay as it was at the beginning of 2014 (Table 4). Analysing the results of the CHF loan simulation the repaid interests and principals are more divergent than in the optimistic scenario. The interest paid by in case of the highest income category is even lower than in case of the original loan. This value considers the income category I. is almost twice as the mentioned ones. On the basis of the principal calculations, we can state the lower value belongs to the category I (because of the foregone interests). The total cost indicates that the lowest cost is still denoted by the original loan, but in the realistic sce- nario the total repayment of category III appeared to be more favourable for the debtors, than entering the exchange rate barrier.

Data of EUR based loan simulation are evaluated more homogeneous than the abovementioned realistic CHF simulation results. Interests take values between 2.1 and 3 million Ft. Greater differences are presented by the principal repayment: the highest values are related to the conditions of income category II and III.; and category I indicates similar cost as the original loan. As for the total costs the most beneficial is still the original loan in this scenario, it is followed by the income category I. and the exchange rate barrier. An interesting result that the repayment based on income category II. turned out to be the most expensive method.

Table 4. Repaid amounts of CHF and EUR based loans in case of realistic scenario

\begin{tabular}{|l|c|c|c|c|c|}
\hline \multicolumn{1}{|c|}{ Condition } & Interest (HUF) & $\begin{array}{c}\text { Ratio of interest } \\
(\%)\end{array}$ & Principal (HUF) & $\begin{array}{c}\text { Ratio of princi- } \\
\text { pal (\%) }\end{array}$ & $\begin{array}{c}\text { Total repayment } \\
\text { (HUF) }\end{array}$ \\
\hline Original loan (CHF) & 1810315 & $19,92 \%$ & 7275925 & $80,08 \%$ & 9086239 \\
\hline Exchange rate barrier* & 2130455 & $21,86 \%$ & 7614976 & $78,14 \%$ & 9745430 \\
\hline Category I** & 3167650 & $30,68 \%$ & 7157293 & $69,32 \%$ & 10324943 \\
\hline Category II & 2278111 & $22,33 \%$ & 7921826 & $77,67 \%$ & 10199937 \\
\hline Category III & 1745769 & $18,06 \%$ & 7921826 & $81,94 \%$ & 9667595 \\
\hline Original loan (EUR) & 2626845 & $30,26 \%$ & 6053592 & $69,74 \%$ & 8680436 \\
\hline Exchange rate barrier* & 2808660 & $30,58 \%$ & 6375115 & $69,42 \%$ & 9183775 \\
\hline Category I** & 2996818 & $32,95 \%$ & 6097586 & $67,05 \%$ & 9094404 \\
\hline Category II & 2598053 & $26,60 \%$ & 7167298 & $73,40 \%$ & 9765351 \\
\hline Category III & 2146084 & $23,04 \%$ & 7167298 & $76,96 \%$ & 9313383 \\
\hline
\end{tabular}

* Capitalised interest in case of CHF based loan: $333290 \mathrm{Ft}$, and EUR based loan: $316051 \mathrm{Ft}$

** Foregone interest in case of CHF based loan: $764533 \mathrm{Ft}$, and EUR based loan: $1069712 \mathrm{Ft}$

Source: Own calculations 
Table 5. Repaid amounts of CHF and EUR based loans in case of pessimistic scenario

\begin{tabular}{|l|c|c|c|c|c|}
\hline \multicolumn{1}{|c|}{ Condition } & Interest (HUF) & $\begin{array}{c}\text { Ratio of interest } \\
(\%)\end{array}$ & Principal (HUF) & $\begin{array}{c}\text { Ratio of princi- } \\
\text { pal (\%) }\end{array}$ & $\begin{array}{c}\text { Total repayment } \\
\text { (HUF) }\end{array}$ \\
\hline Original loan (CHF) & 1869069 & $19,59 \%$ & 7670889 & $80,41 \%$ & 9539958 \\
\hline Exchange rate barrier* & 2380622 & $22,36 \%$ & 8267456 & $77,64 \%$ & 10648078 \\
\hline Category I** & 3853266 & $35,00 \%$ & 7157293 & $65,00 \%$ & 11010559 \\
\hline Category II & 2606943 & $24,76 \%$ & 7921826 & $75,24 \%$ & 10528769 \\
\hline Category III & 1932340 & $19,61 \%$ & 7921826 & $80,39 \%$ & 9854166 \\
\hline Original loan (EUR) & 2725404 & $29,68 \%$ & 6456341 & $70,32 \%$ & 9181745 \\
\hline Exchange rate barrier* & 3086570 & $30,48 \%$ & 7041150 & $69,52 \%$ & 10127721 \\
\hline Category I** & 3414999 & $35,90 \%$ & 6097586 & $64,10 \%$ & 9512585 \\
\hline Category II & 2598053 & $26,60 \%$ & 7167298 & $73,40 \%$ & 9765351 \\
\hline Category III & 2305594 & $24,34 \%$ & 7167298 & $75,66 \%$ & 9472892 \\
\hline
\end{tabular}

* Capitalised interest in case of CHF based loan: $386637 \mathrm{Ft}$, and EUR based loan: $367198 \mathrm{Ft}$

** Foregone interest in case of CHF based loan: $764533 \mathrm{Ft}$, and EUR based loan: $1069712 \mathrm{Ft}$

Source: Own calculations

\section{Pessimistic scenario}

Pessimistic scenario includes the possible results in case of weak exchange rates and relatively high interest rates (Table 5). Regarding CHF loans more than two times interest is paid by the lowest income based scheme, than in case of the original loan. In this scenario the exchange rate has the highest principal cost. Debtors of the original loan could save 600 thousand $\mathrm{Ft}$ not entering the exchange rate barrier. Examining the total cost the original loan and the highest income category represent the lowest values. Category II. resulted similar cost as the exchange rate barrier and the most expensive condition is the lowest income category based condition.

EUR loan interests exceed 3 million Ft in case of the exchange rate barrier and income category I. Analysing the principal costs, there is only two conditions (original loan, income category I) under 7 million Ft. The results indicate that 1 million Ft difference appears between the exchange rate barrier and the income category I. principal payments. It is easy to determine that in the pessimistic scenario the most expensive condition in case of EUR loans is the exchange rate barrier and the most favourable is the original loan.

\section{Conclusions}

Several reasons led to the indebtedness of the population in Hungary. Since then then the government made significant progress in avoiding similar situations emerge in the future: now interest rates are strictly regulated and one-sided contract modifications are not allowed only in some limited situation. Low financial literacy appears to be a national problem in Hungary. The ordinary man is not aware of basic financial concepts like risk of interest or exchange rate, or even APR (Annual Percentage Rate). I suggested basic financial education should be included in the elementary and high school education. Some commercials are already on TV presenting basic financial concepts, which is considered a good way to reach the older generation. It should be preferable to have this kind of informing notes in newspapers too. The mentioned steps could help clients make responsible financial decisions (independently from their profession) regarding loans, credits and also investments.

Different circumstances applied in the examined scenarios significantly influenced the repaid amount of money regarding each condition. The least total repayment belonged to the original loan in every scenario. In the optimistic scenario, it is not worth to convert the loans to HUF when the interest rates and exchange rates have a downward trend. The terms used in optimistic calculations are not likely to characterise the near future. In case of realistic scenario after the original CHF loan, the exchange rate barrier and income category III. based loans have similar costs. We should highlight that there is still exchange rate risk considering the exchange rate barrier, not like in case of the income based condition where the loan is converted so there is no exchange risk any more. Moreover calculating with a high income resulted in a shorter duration too. Examining the costs of the Euro based loans the income category I. based loan is competitive with the original loan. Thanks to the foregone interest the debtors could pay back almost equal money as they should have paid with the original one, but longer time is available for them so the monthly burden also decreases. Based on the results provided by the pessimistic scenario of CHF loans we can state that the exchange rate barrier represents the highest principal cost. This is the scenario where it is worth to convert the CHF based loans to HUF loans, mainly if we have an income belonging to category II. or III. Regarding EUR based loans in pessimistic scenario exchange rate barrier is the least favourable condition. The models' distorting factor can be that the future exchange rates and interest rate are estimated as a constant number, however both can be volatile.

As for the survey of the Hungarian National Bank, 75\% of the respondents did not join the exchange rate cap system because of the following three reasons: larger instalment after the fix exchange rate period, lack of faith and waiting for a better opportunity. Besides that, they are eligible for the aid just simply did not abuse it, so they could join to the income 
based repayment. Debtors choosing this method can calculate their instalments monthly, because it is fixed to their salary and it grows only if they are better off. Moreover, they can complete the payments even before it was planned. With the income based repayment the debtors can calculate with a fix instalment every month and it is harmony with the government's strategy to eliminate exchange risk and uncertainty from the portfolios.

\section{References}

Balás T \& Nagy M (2010): A devizahitelek átváltása forinthitelekre. Hitelintézeti szemle. Vol. 9. No. 5., p. 416-430.

Berlinger E \& Walter Gy (2013): Unortodox javaslat a deviza és forintalapú jelzáloghitelek rendezésére. Hitelintézeti Szemle. Vol. 12. No. 6., p. 469-493.

Bloem AM. \& Freeman R (2005): The Treatment of Nonperforming Loans. Eighteenth Meeting of the IMF Committee on Balance of Payments Statistics Washington, D.C., June 27-July 1 p.15.

Burgerné Gimes A (2011): A kelet-közép-európai országok válsága a globális krízis tükrében - válaszok a válságra. Statisztikai szemle. Vol. 89. No. 6., p. 645-666.

Dübel HJ (2012): CEE Mortgage Market Regulation. Berlin. 83.p.

Holmár K (2012): Mérlegen a valóság, avagy a hazai devizahitelezés nyertesei és/vagy vesztesei. Hitelintézeti szemle. Special Issue. p. $33-43$.
Hudecz A (2012): Párhuzamos történetek. Közgazdasági szemle. Vol. LIX.. April., p. 349-411.

Marsi E (2012): A magyar bankrendszer teljesítményének értékelése a közép-kelet-európai bankrendszerek tükrében. Hitelintézeti szemle. Vol. 11. No. 6., p. 516-530.

Nyeste O \& Árokszállási Z (2012): Devizahitelezés Magyarországon - régiós makrogazdasági, fiskális és monetáris politikai megközelítésben. Bp. Magyar Bankszövetség. p. 154-171.

Sándorné Új É (2003): Pénzügyek a gyakorlatban. Pécs. Penta Únió Oktatási Centrum, 347.p.

Varga L. (2008): A magyar szuverén CDS-szpredek információtartalma. MNB-studies 78. p.30

7Sigma Kft. (2010): Egy piaci kudarc története - okok, körülmények, tanulságok A hazai lakossági hitelpiac tíz éve, Study (GVH VKK/3/2009), Bp. p. 42.

Romanian National Bank (RNB) Statistics http://www.bnro.ro/ Loans-and-Deposits-by-County-3211.aspx

Polish National Bank (PNB) Statistics http://www.nbp.pl/homen. aspx?f=/en/statystyka/naleznosci/naleznosci.html

MNB (Hungarian National Bank) Financial Stability Reports 20052014 http://english.mnb.hu/Root/ENMNB/Kiadvanyok/mnben_stabil MNB (Hungarian National Bank): Guide to the regulation concerning FX lending in Hungary https://felugyelet.mnb.hu/data/cms2408096/ ESRB_guidelines_compliance.pdf

Act CXLVIII of 2011 (Hungary)

Act LXXV of 2011 (Hungary)

Act CLXXIII of 2013 (Hungary)

Government Decree 128/2012 